\title{
QUEEN'S
UNIVERSITY
BELFAST
}

\section{Voiceless but empowered farmers in corporate supply chains: Contradictory imagery and instrumental approach to empowerment}

McCarthy, L., Touboulic , A., \& Matthews, L. (2018). Voiceless but empowered farmers in corporate supply chains: Contradictory imagery and instrumental approach to empowerment. Organization.

https://doi.org/10.1177/1350508418763265

\section{Published in:}

Organization

\section{Document Version:}

Peer reviewed version

Queen's University Belfast - Research Portal:

Link to publication record in Queen's University Belfast Research Portal

Publisher rights

(c) 2017 SAGE. This work is made available online in accordance with the publisher's policies. Please refer to any applicable terms of use of the publisher.

\section{General rights}

Copyright for the publications made accessible via the Queen's University Belfast Research Portal is retained by the author(s) and / or other copyright owners and it is a condition of accessing these publications that users recognise and abide by the legal requirements associated with these rights.

Take down policy

The Research Portal is Queen's institutional repository that provides access to Queen's research output. Every effort has been made to ensure that content in the Research Portal does not infringe any person's rights, or applicable UK laws. If you discover content in the Research Portal that you believe breaches copyright or violates any law, please contact openaccess@qub.ac.uk. 


\title{
Voiceless but empowered farmers in corporate supply chains: Contradictory imagery and instrumental approach to empowerment
}

\author{
Lucy McCarthy, Anne Touboulic* \& Lee Matthews
}

\begin{abstract}
There have been calls for a shift of focus towards the political and power-laden aspects of transitioning towards socially equitable global supply chains (Montabon et al., 2016; Matthews et al., 2016). This paper offers an empirically grounded response to these calls from a critical realist stance in the context of global food supply chains. We examine how an imaginary for sustainable farming structured around an instrumental construction of empowerment limits what is viewed as permissible, desirable and possible in global food supply chains. We adopt a multimodal Critical Discourse Analysis (CDA) to examine the sustainable farming imaginary for smallholder farmers constructed by one large organization, Unilever, in a series of videos produced and disseminated on YouTube. We expose the underlying mechanisms of power and marginalization at work within the sustainability imaginary and show how empowerment means the creation of new dependencies for these farmers. We recontextualize the representations to show that while the imaginary may be commercially feasible, it is less achievable in terms of empowering smallholder farmers.
\end{abstract}

*Corresponding author: anne.touboulic@,nottingham.ac.uk 


\title{
Voiceless but empowered farmers in corporate supply chains: Contradictory imagery and instrumental approach to empowerment
}

\begin{abstract}
There have been calls for a shift of focus towards the political and power-laden aspects of transitioning towards socially equitable global supply chains. This paper offers an empirically grounded response to these calls from a critical realist stance in the context of global food supply chains. We examine how an imaginary for sustainable farming structured around an instrumental construction of empowerment limits what is viewed as permissible, desirable and possible in global food supply chains. We adopt a multimodal Critical Discourse Analysis (CDA) to examine the sustainable farming imaginary for smallholder farmers constructed by one large organization, Unilever, in a series of videos produced and disseminated on YouTube. We expose the underlying mechanisms of power and marginalization at work within the sustainability imaginary and show how "empowerment" has the potential to create of new dependencies for these farmers. We recontextualize the representations to show that while the imaginary may be commercially feasible, it is less achievable in terms of empowering smallholder farmers.
\end{abstract}




\section{Introduction}

Transforming supply chains is fundamental to transitioning to more socially equitable societies (Mohrman and Worley, 2010), and this transformation is one of the societal grand challenges that management research should endeavour to tackle (George et al., 2016). Despite the need for large coordinated efforts, the largest body of research in this area is concentrated in the insular field of sustainable supply chain management (SCM). The term insular is used in recognition of the way in which this field, despite its interdisciplinary connections, has developed into a relatively paradigmatically homogeneous body of work, primarily adopting a rationalist and technological approach, self-restricting its exchanges and dialogues with other areas in organizational studies and social science more broadly (Matthews et al., 2016).

There have been calls for increased paradigm diversity in the field of sustainable SCM and for a shift of focus on and engagement with the political and power-laden aspects of transitioning towards ecologically resilient and socially equitable global supply chains (Montabon et al., 2016; Matthews et al., 2016). Montabon et al (2016: 11) note that "the vast majority of research and practice regarding sustainable supply chains has followed an instrumental logic, which has led firms and supply chain managers to place economic interests ahead of environmental and social interests" and that this “instrumental logic dominated by economics (...) is antithetical to humanity's wellbeing". 
This paper offers an empirically grounded response to these calls by examining issues of marginalization and empowerment in global food supply chains from a critical realist stance. While other fields have developed these concepts, to our knowledge they have thus far not been interrogated in the field of corporate sustainability, despite multiple acknowledgements of the necessity to empower communities and workers for a sustainable future. We recognize the need for a critical questioning of sustainability in corporate supply chains and for repositioning the debate within the realm of the political and social. Our view aligns with that of Blowfield and Frynas who argue that "by leaving unquestioned [sustainability]'s reliance on consensus and win-win outcomes, we leave the poor and marginalized exposed to the possibility of further exploitation and marginalization as a result of inequitable exertions of power" (2005: 513).

Global food supply chains exemplify supply chain capitalism and the hegemony of the "giant corporation" (Tsing, 2009). Extended privately controlled food production and consumption networks have emerged through increased coordination of the global agricultural trade, global sourcing and contractualization in search of efficiency (Young and Hobbs, 2002). These networks are controlled mainly by a small number of Western large food retailers and manufacturers, a feature described as 'buyer-driven (-ness)' (Gereffi, 1994; Prieto-Carron, 2008). The consequences of such imbalanced power relations are immense for how sustainability is addressed, as these corporations have attempted to organize and govern their supply chains through the imposition of 
standards and codes of conducts (Thompson and Scoones, 2009). In this way they have shaped the sustainability agenda according to restricted views of social justice and 'vested interests' (Henson and Humphrey, 2010).

Few studies have explored the political and social aspects of sustainability in global supply chains. Contributions by Prieto-Carron (2006; 2008), Loconto (2015), Barrientos et al. $(2014 ; 2003 ; 2005)$ on women workers, corporate codes of conducts are noteworthy exceptions. They draw on the feminist literature to unveil (limits to) processes of emancipation and empowerment and to critically assess the limited impact of corporate social and environmental initiatives. Our contribution adds to this perspective by considering farmers (i.e. agricultural raw materials suppliers) as marginalized subjects in global food supply chains. We examine what the sustainability imaginary, as a "shared socio-semiotic system" (Levy \& Spicer, 2013: 3) enabling collective understanding and action, means for smallholder farmers in global food supply chains and what it implies about underlying mechanisms of power and marginalization. We consider how the sustainability imaginary is structured around an instrumental construction of empowerment.

We adopt multimodal CDA to examine the sustainability imaginary for farmers crafted by one large organization, Unilever, in the complete population of videos disseminated on their own YouTube channel (Unilever YouTube channel, 2017) between 2011 and 2016 that mention and visually represent farmers. We are particularly interested in 
interrogating how the dominant imaginary limits what is viewed as permissible, desirable and possible in this context.

\section{Framing and contextualizing}

\section{Narratives and images of sustainability: marginalized voices}

Sustainability is a social imaginary (Castoriadis, 1997), that is a vision for change that articulates how the world could or ought to be (Fairclough, 2009). Imaginaries allow actors to collectively imagine and enact solutions to highly complex issues (Levy and Spicer, 2013; Wright et al., 2013). Many have argued that the social imaginary for sustainability has been 'hijacked' by multinational companies (Welford, 1998) who now have a central role in defining the sustainability agenda and are increasingly promoted as the main agents of change to drive sustainability (Banerjee, 2008). It is therefore critical to understand how these companies frame the meaning of sustainability through narratives and images.

Discourse analysis enables researchers to analyze power struggles at play between various actors in their attempts to assert the legitimacy of narratives and meaning construction around organizational issues (Vaara and Tienari, 2008; Barros, 2014). Hence there is a possibility to explore which are the dominant discourses and the dissonant ones, the dominant voices and the marginalized ones. 
In considering questions of power, marginalization and discourse our work resonates with postcolonial theory (Prasad, 2003; Özkazanç-Pan, 2008). Research in this area draws attention to the silencing of non-Western, marginalized subjects and critiques Western management discourse by exposing and questioning their imperialist assumptions. Representations are at the heart of the postcolonial literature, as images serve to construct "the other" and are "central to the process of reproducing colonial power" (Said, 1979). Wilson's (2011) postcolonial work uses the Marxist lens of processes of exploitation to analyze the representation of women in non-governmental organizations campaigns. She argues that representations of women in the neoliberal development discourse have shifted towards more positive images that are similar to 'representations of 'productive and contented' workers in colonial enterprises, and like them operate to legitimize and reinforce existing structures and relationships and to ensure that resistance and the desire for transformation remain out of the picture" (Wilson, 2011: 316).

Some research in the field of sustainability has considered narratives and images, for instance in the context of large companies trying to assert their legitimacy on sustainability issues (Barros, 2014) or in assessing the role of corporate social responsibility reports in camouflaging real sustainable development issues (Boiral, 2013). There is however a dearth of contributions that have explored discursive practices around sustainability in supply chains. Considering the underlying structural 
power dynamics at play in such contexts (Touboulic et al., 2014), one can expect to shed some light on marginalization practices between buyers and suppliers by specifically considering the construction of discourses as interrelated to material practices.

Work that has considered more covert power dynamics around sustainability, observable through inter-related material and discursive practices, is particularly interesting for our research. Research on gender and global value chains (Prieto-Carron, 2006; Prieto-Carron, 2008; Barrientos, 2014; Barrientos et al., 2003; Tallontire et al., 2005) highlights how the governance structures of global value chains, rooted in imbalanced power relations, influence the social practices developed and implemented by actors in this context. They critique codes of conduct, standards and certification in that they reproduce these imbalanced power structures (i.e. increase dependency) and actually fail to deliver the goals they are set out to achieve (i.e. increased labour rights and gender equality). This is because they do not address deeply embedded structures of inequality, particularly with regards to the gendered division of labour in global production, i.e. women occupying the more precarious positions (Prieto-Carron, 2008).

Nelson and Tallontire (2014) explore the interrelated material and ideational powers at work in the shaping and implementation of social and environmental standards in global value chains. They challenge the ability of the dominant and powerful narrative of "global sourcing" (i.e. put forth by multinational companies and focusing on security of 
supply) to effectively "transform agriculture to sustain livelihoods for workers and smallholders in equitable and sustainable ways" (Nelson and Tallontire, 2014: 495).

\section{Unilever: the giant corporation as discourse shaper}

The sustainability question in global food supply chains cannot be detached from its structural characteristics, hence we focus our analysis on one giant corporation, Unilever. The Anglo-Dutch multinational has substantially shaped the discourse and actions on sustainability in food supply chains.

Unilever, a consumer goods company, had a turnover of $€ 52.7$ billion in 2016 . A selfproclaimed 'force for good' (Unilever, 2015), Unilever has “ambitious plans for sustainable growth and an intense sense of social purpose" (Unilever, 2017). It is often lauded by others as an industry leader, solidified by being named as such 15 times in 16 years on the Dow Jones Sustainability Index (DJSI). With 2.5 billion people using their products daily (Unilever, 2017) and 58\% of their business in emerging markets Unilever has a far reach. The current CEO of Unilever, Paul Polman, is known for his views on responsible profit making and long-term orientation (Ruddick, 2016). Given the dedication to equality Unilever are self-identified (Burn-Callander, 2015), and externally recognized (DJSI, Behind the Brands, CDP) as a leader within the 'discourse coalition' (Hajer, 1995) on corporate sustainability in general and sustainable farming in particular. 
Oxfam's Behind the Brands initiative (Oxfam, 2016) has consistently ranked Unilever as first or second out of the top 10 biggest food companies across seven sustainability indicators. Oxfam reports a consistent rise in Unilever's overall sustainability score between 2013 and 2016 (Figure 1).

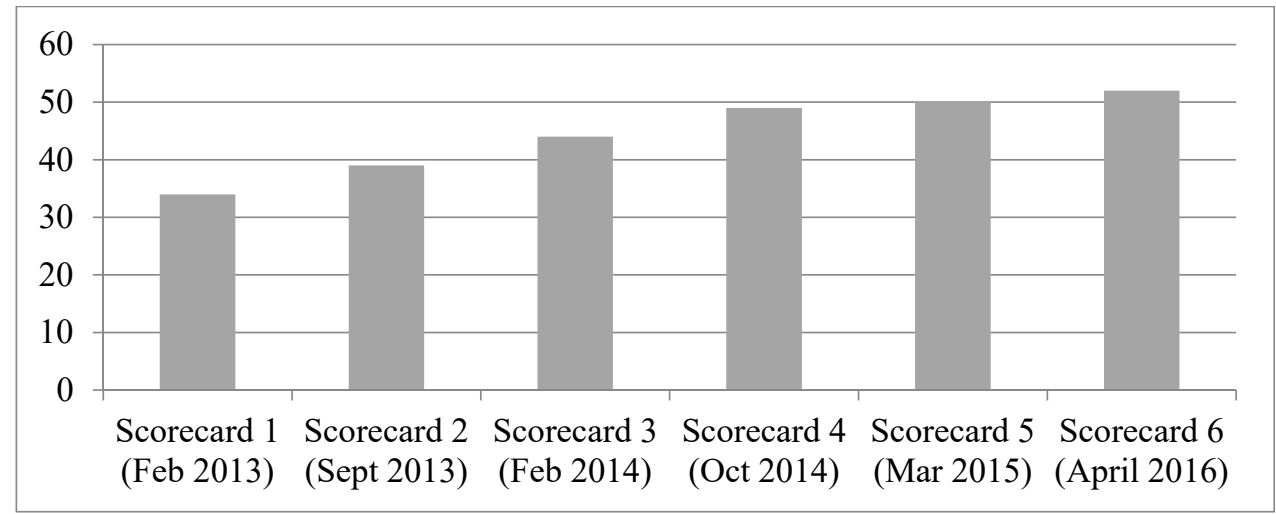

Figure 1. Oxfam Behind the Brand company scorecards: Unilever overall scores (Source: Authors)

Unilever's performance in the categories "farmers", "women" and "workers" that are relevant to this work, has been reported as either consistently fair/good or improving. This notable exception is around "women", which remains comparatively low. 


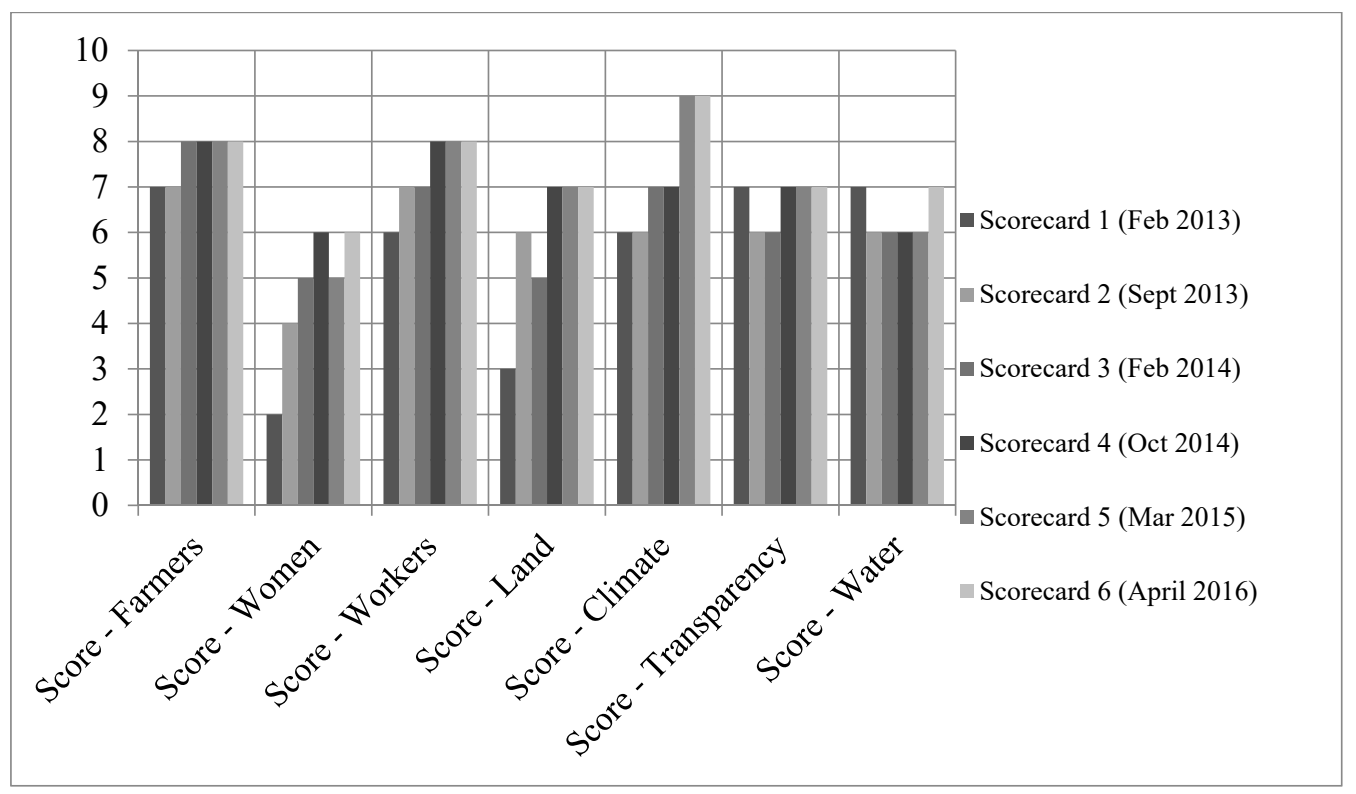

Figure 2 - Oxfam Behind the Brands: Unilever's scores on sustainability issues (Source: Authors)

Oxfam's approach to assessing companies' performance is solely based on the analysis of publicly available information disclosed by the companies themselves, and "the scorecard does not directly assess actual conditions on farms and whether the policies of the Big 10 are implemented and enforced" (Oxfam, 2013: 6). This is indicative of the difficulty of reporting impartial data and of measuring the actual impact of practices implemented by such large corporations. It substantiates Unilever as a powerful discourse-maker.

The case of Unilever is considered exemplary within its industry and is consistently offered as an example of good practice for its sustainable agriculture strategy, as such it is an instrumental case study. Yet many of its competitors are working on similar 
strategies and are operationalizing the same sustainability imaginary. For example, Nestlé has an empowerment strategy for women farmers in its cocoa supply chain that is similar to Unilever's (Nestlé, 2015). By examining Unilever's imaginary, we seek to provide insights into the broader issue of sustainable farming and its feasibility as shaped by other large multinationals.

\section{Methodology}

\section{A realist approach to $C D A$}

To achieve our aim of engaging with the political and social aspects of supply chain sustainability, we adopt a realist approach to discourse analysis (Phillips and Oswick, 2012; Reed, 2004) in order to embrace the 'relational' character of discourses in their interaction with social structures and practices (Fairclough, 2005). There has been much interest in how discourse through text and visuals is constructed by actors and used as a way to make sense of certain issues and legitimate responses or practices in relation to this issue, for e.g. gender relations at work (Barros, 2014; Vaara and Tienari, 2008).

Critical realism suggests several levels of analysis. Within the level of the 'actual' we have processes and events that are caused by the social structures that exist at the level of the 'real'. The relations of causality are highly complex between the levels of the 'real' and 'actual' and are mediated by social practices. Discourse is an important element of social practices. Texts are part of processes and events and draw upon 
discourses in their production (Sims-Schouten et al., 2007; Fairclough, 2005). At the level of the 'empirical' the structures and the processes of the real and the actual are experienced and made sense of by individuals.

This enables us to explore the experiences at the level of the empirical contained in the primary data and relating them to broader social practices through processes of retroduction (Fletcher, 2017), which consists of a back-and-forth between the empirical data - the videos in our study - other sources of data, literature and theory (Leca and Naccache, 2006). It is through this iterative process that underlying mechanisms can be exposed and we can explore the domain of the real. Our analysis concerns two levels of the 'real': the ideally and socially real; and the relationships between them. Discourses that constitute imaginaries - such as the sustainable farming imaginary in this study are ideally real as they have 'causal efficacy', i.e. an influence on behaviour and actions. They are socially real as they concern social practices and social structures. The value of a critical realist approach to discourse analysis is that it allows the retroduction of statements about empirical reality from discursive artefacts. In our case, we move from the discourses of a powerful, dominant actor in the videos to probably statements about their empirical reality.

Our approach to CDA is therefore intrinsically multi-dimensional, exploring discursive practices, their underlying generative mechanisms and extra-discursive contexts (SimsSchouten et al., 2007). We follow the meta-theoretical assumption that social 
interactions cannot be understood fully without reference to the discursive practices in which social agents are engaged (Wood and Kroger, 2000). Discourse constructs what is possible for social agents to be and do by legitimizing which identities, ideas and activities are acceptable and which are not (Foucault, 2002; Phillips and Hardy, 2002). It does this through the construction of the subject positions social agents inhabit and the concepts they use to understand the world (Phillips et al., 2008).

The social agents we are interested in are the giant corporation (Unilever) and the farmers that supply them and it is considered that interactions between them will be largely 'discourse-led' (Fairclough, 2009). In order to understand how these social agents work together to effect change, we explore the discursive practices via the videos created by these powerful actors within which such efforts are enacted and how these interrelate with wider social practices in relation to global food supply chains. A key discursive practice within this process is the development and enactment of imaginaries for change.

\section{Analysis}

We followed Wood and Kroger's (2000) proposed two staged approach to analysis. The first is a sensitizing stage in which the analyst familiarizes themselves with the data. The second stage is the formal analysis and in this case concerns the sustainability imaginary for farmers within Unilever's videos. 
Having agreed on the search criteria we initially returned 32 videos containing the term farmer on the Unilever YouTube channel. We excluded any videos which did not contain imagery or rhetoric around farmers and were left with an agreed sample of 22 videos that had been created and published on the site from 2011-2016 (see Appendix $1)$.

We utilized a multimodal CDA (as illustrated in Table 3) as it allows for the incorporation of other forms of resources in the analysis. Extending in this instance beyond the text, to the spoken language, the written language, imagery and gestures, this allows us to explore multiple meanings (O'Halloran, 2011). This approach allows understanding of intersemiosis, the 'relations arising from the interaction of semiotic choices'(O'Halloran, 2011: 121). We use this to explore the interactions, relationships and contradictions between text, imagery and audio representations in order to begin to unpack the narratives and counter narratives being simultaneously presented. The analysis of these multiple modes facilitates a richer deeper understanding of the discourse as it shifts between different resources presented in the empirical data.

Working in isolation, each researcher undertook a multimodal CDA, coding each of the 22 videos thematically. This constituted our open coding process where we took note of the context (e.g. imagery surrounding the farmers and how we, the consumer/audience, are positioned relative to the farmer) as well as the content (discourse design and it's fitness for purpose). We then discussed our codes, refining and collapsing as we 
progressed. Returning for a final analysis of the videos some new terms emerged and some codes were collapsed and others dismissed. Through constant comparison techniques and interpretive analysis of these established codes, we established relationships between codes.

\section{Research ethics: An 'ethics of care' approach}

The research produces a number of ethical issues that need to be reflected upon. First, we are working with images that were not produced by the research team and that were produced for another purpose. Second, many of these images represent 'postcolonial subjects' (Spivak, 1988) and the research team working with these images consist of three Western academics working for British institutions. Given the nature of these issues, our reflections need to focus on the question of power and postcolonialism.

The farmers in agreeing to appear in the videos would not have anticipated that their images and text would become empirical material for an academic piece of work and the power we exercise in taking these videos and using them for our own purpose must be acknowledged. We recognize the power that we exercise through of our representations, which may be very different to how the farmers see themselves and their circumstances. Like Unilever, we are making claims about this group without being part of it and this is necessarily an act of 'epistemic violence' (Spivak, 1988). 
Our ethical approach is that of an 'ethics of care' (Mauthner and Doucet, 2003) in which the welfare of the farmers is our primary concern and the research is motivated by a commitment to their emancipation. While our sense of having an 'ethics of care' can again be seen as an instance of postcolonialism, we have taken great care to reflect upon our own representations of this group and are clear that we are not speaking for them. To achieve this, we have maintained a consistent focus in our work on Unilever's imaginary for sustainable farming, and the part that Unilever's representational work plays in this. 


\section{Findings}

This section examines Unilever's sustainability imaginary for the smallholder farmers within its supply chains. The central concept in Unilever's sustainability imaginary is 'empowerment'. Unilever have constructed an instrumental concept of empowerment in which farmers are empowered to achieve Unilever's commercial goals, principally securing supply within their agricultural supply chains. While in instances this improves the socio-economic conditions of the farmers within these supply chains, the farmers' dependence upon Unilever is increased. The videos use a reality crafting strategy to communicate Unilever's sustainability imaginary. In the videos, Unilever craft their interpretation of their role, the role of the farmers and their relationships around the sustainability agenda. The videos exemplify hyper-reality as they seek to convey "environments that are better" (Cypher \& Higgs, 1997 : 111 cited in Garland et al., 2013). Hyper-reality (Garland et al., 2013) is evidenced in the luminosity and vividness of the images within the videos. The customer-centric videos may provide the context for the viewers to craft their interpretation of sustainable farming in relation to their identity as consumers (Garland et al., 2013). Hence Unilever's imaginary "binds together diverse activities of production and consumption and gives them directions" (Wright et al., 2013)

There are two interrelated pillars, evidenced through practices, narrative and imagery, that together form the sustainability imaginary of empowered smallholder farmers (code 
map in Appendix 2). These pillars are the construction of sustainability and empowerment and the construction of subject positions, and are used to structure the remainder of this section.

\section{Construction of sustainability and empowerment strategies}

\section{Sustainability}

Unilever adopts an instrumental concept of sustainability based on a win-win logic. They appear to use a problematizing strategy around issues that they can help solve (Maguire and Hardy, 2009). Sustainability is a key concept within Unilever's discourse but is never explicitly defined. Instead, Unilever's concept of sustainability is constructed through a series of goals (e.g. "source $100 \%$ of our materials sustainably by 2020” V1), practices (e.g. “nutrition programme” V7, funding programmes to acquire technology such as "humidity probes" V13) and imagery (knowledge sharing for sustainable farming as illustrated through images in e.g. V1 "Knorr Farmer Summit 2015 ”. These practices relate to the central organizing concept of empowerment.

Unilever's sustainable farming imaginary is centred on issues of yield improvement, quality, agricultural training, access to finance and the market. There is a lack of clarity of the centrality of these issues to the farmers. In V14 on sustainable sourcing the narrator, representing Knorr, explains: "over the years we have worked with farmers to help them reduce their costs and increase their yields" (0:55 -0:58). In V7, Mr. Vinod 
identified as a farm owner and partner, discusses sustainable drip irrigation, which according to him is "very important for gherkins" resulting in "the yield for farmers to increase by 20/25\%" over two years since its implementation. There are specific references to practices rolled out to Madagascan Vanilla farmers; these are "water protection", "farming without chemicals", "no littering" and "changing the farmers' approach to washing" (V2).

A recurring idea is that farmers need guidance and aid. The outcomes of these 'aid' programmes are presented in the context of what is beneficial for the consumers. There is narrative around the need to educate the suppliers and bring them up to speed with sustainability. The training and education theme is evident in the textual and spoken discourse as well as in the images. In V5, V6 and V7 there are verbal references to training ("Since 2011 we have helped to train 18,000 tea smallholders to prepare them for Rainforest Alliance certification” V5, 0:30 - 0:33) and images of the training being delivered in situ as shown in Figure 3.
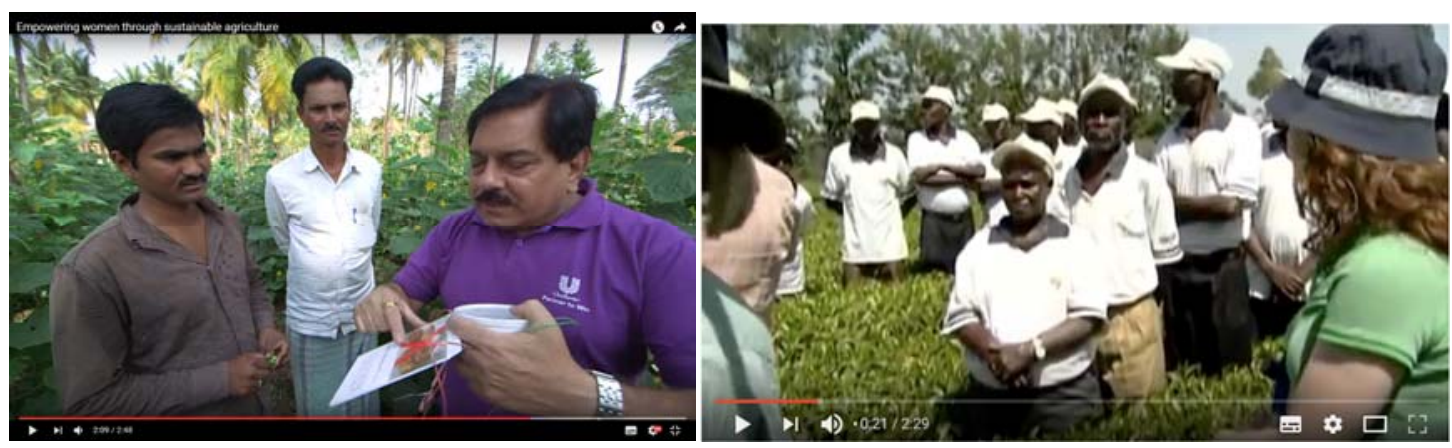

Figure 3. Farmers being trained and educated in V7 and V6: colonial representations? 
Related to the theme of farmer training are concepts of quality and yield. A low yield can be problematized and held up for Unilever to help fix. This problematization is made possible because of a broader system whereby farmers produce crops for export. In V5 a Unilever manager discusses tea farming: "Among the many ways that we are helping to improve tea farming includes teaching farmers to reduce their fertilizer use and increase their yields. And this improves their soil. It saves them money and helps them earn more." Statements like this are common in the videos and simplify the linkages between complex issues such as yields and soil quality, and reduction in costs, savings and earnings.

Quality improvement is problematized rather than poor quality, as quality is a core issue in terms of the consumer. While improvement is acceptable, framing a product as low quality may be unacceptable. There is clear evidence of consumer centricity and the quality product is the critical link between production and consumption. Throughout there are images conveying the high quality of the products through the use of bright colours, high definition and close-ups (Figure 4). 

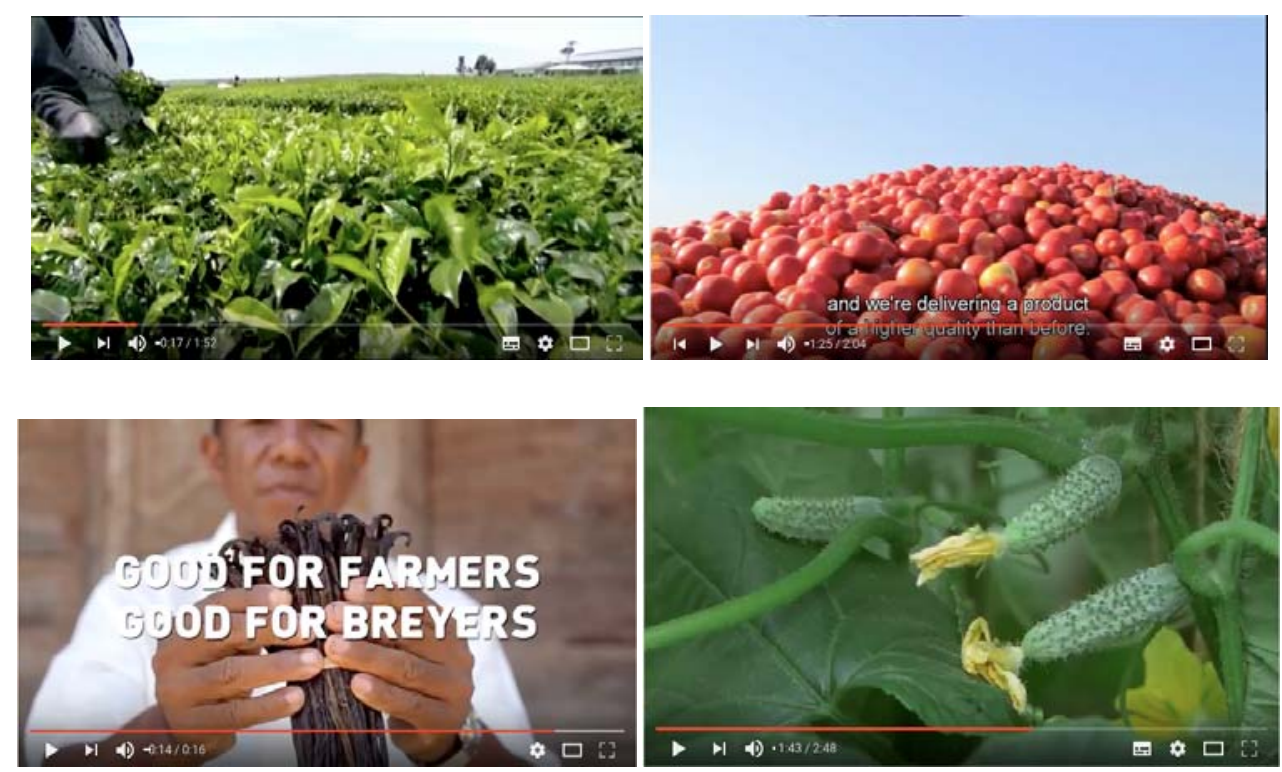

Figure 4. High quality products: vivid images from V4, V7, V9 and V13

This is illustrated in textual evidence. In V13 both farmer and Knorr chef discuss product quality:

"Sustainability is important in our farm because we have exceed our production limits and we are delivering a product of higher quality than ever before" (Farmer, V13)

In V16, Barry Callebaut's Chief Innovation Officer, supplying chocolate for Unilever products, explains:

"The second thing we're doing together in sustainability is making sure that the quality of the cocoa improves and if that does improve then cocoa farmers will make a better livelihood and will stay in cocoa farming and will have better 
livelihoods for their families as well and I think that helps all of us in terms of sustainability.”

The problematized issues of quality and yields improvement appear to signal the dependence structure at play in the global supply chains in which Unilever is involved. In linking the enhancement of farmers' livelihoods to yields and quality improvement, the responsibility for this enhancement is attributed to the farmers themselves.

\section{Empowerment}

Empowerment is not defined by Unilever and is constructed through a bewildering series of targets ("we aim to empower 5 million women across our value chain" V10) and practices ("agricultural training" V7). Empowerment is constructed as a means to various ends such as poverty reduction, gender equality and improved supply chain performance.

Unilever craft a new definition of empowerment, distinct from those based on the principles of self-determination and self-efficacy (Rappaport, 1995; Conger and Kanungo, 1988), and focuses on the empowerment of farmers to achieve Unilever's aims. The ends for which empowerment is a means are concretely defined as quantifiable targets. These ends can be classified at two levels: social ends and economic ends at the level of the supply chain. At the social level, Unilever seeks to contribute towards high-level goals such as poverty reduction and gender equality (V10, 
V11, V20, V21), however the focus remains on delivering value for the business and is hence instrumental. At the economic level, Unilever seeks to improve supply chain performance through improving the quality of the farmers' produce and increasing the yields produced. Empowerment is the means to achieve all of these goals and includes the following practices: decision making, skill acquisition through access to training and the promotion of rights.

Empowerment is constructed as a means to improve supply chain performance. In Unilever's discourse, the unnamed structures are the globalized economy in general and agricultural production in particular. Despite being unnamed, they are represented in the persona of the 'trader' who acts as an intermediary between the farmers and the 'market'. The trader abuses this position to drive down the price that farmers are able to get for their crops (V2). This construction of empowerment allows farmers to achieve Unilever's commercial goals, principally securing supply within their agricultural supply chains. Empowerment as constructed by Unilever seems to blur the lines between work and family, business and private spheres, in alignment with the way subject positions are constructed. It resonates with the transcendent magnanimity of their self-constructed role as empowerer, and with the paradoxical discourse around women empowerment as discussed in the following sections.

\section{Construction of subject positions}


Empowerment as the principal order of discourse, produces two subject positions. The perspectives of the 'empowerer' (Unilever) and the 'empowered' farmers are unpacked in this section. We show how Unilever constructs the farmers' voice through the crafting of the videos. There are indications that the full picture is much more complex as obviously the videos are limited in scope (i.e. they are short and consumer-centric). The main group identified by Unilever as beneficiaries of their empowerment is women.

\section{The 'empowerer': self-construction of Unilever and its partners}

The 'empowerers' are high-level actors working for Unilever, its suppliers, and NGO partners. These include executives, heads of programmes, University employees and trainers. The videos are unsurprisingly Unilever-centric, yet the way in which their omnipotence and ownership over the issues and people is conveyed is at times uncomfortable. Examples include the very title of some of the videos such as 'Building a bright future for our smallholder farmers' (V3) or 'Unilever: Empowering women' (V11) which convey this sense of ownership and power and the top-down direction of these initiatives. The 'empowered' (smallholder farmers and agricultural workers) are mainly referred to only relative to Unilever e.g. 'Knorr farmer'.

Business-centrism is prevalent in Unilever's self-designed image. It is particularly salient in videos that clearly link Unilever's brands to sustainability issues. For example in Figure 4, the bottom-left picture clearly states 'Good for farmers, Good for Breyers'. 
In V4, it is explained that it made sense for Unilever to play a role in sustainable tea farming because of their leading position in the market through their Lipton brand. Overall, there is an element of transcendent magnanimity in their self-described role as a 'force for good' (Unilever, 2015).

External actors are often featured in the videos. In V8 the interviewees, all white middle-aged male figures, have names and positions but not all have an affiliation, serving to blur the boundaries between Unilever and its external partners. This is a recurring feature in other videos, where large suppliers such as Symrise (V2 and V15) or Barry Callebaut (V16), are interviewed or talked about with no introduction of who they are and their role in the supply chain.

Unilever and its partners are working to emancipate its farmers from the traders through a purported process of disintermediation in which the farmers get direct access to the market. In reality, Unilever is replacing the intermediary of the trader with its own suppliers. In contrast to the shadowy figure of the exploitative trader, Unilever's chosen intermediaries are constructed as agents of empowerment. Traders are actually never visually represented in the videos and only mentioned in passing for their exploitative practices: "Farmers very often depend on traders that allow them only a very small income” (V7). 
The commercial relationships between the farmers and Unilever's intermediaries are not stated except to indicate that the farmers on occasions may receive a higher price, providing they fulfil requirements in terms of quality. It is not clear what type of contract the farmers have with Unilever's intermediaries and the level of dependence that these contracts create. Unsurprisingly, the farmers shown in the videos are grateful recipients of Unilever's benevolence. There are hints however from the farmers in several videos that the situation is not as ideal as Unilever would like to portray it, which we discuss further in the following sub-section.

\section{The 'empowered' farmer}

In this section, we will look at the individual smallholder farmers, their families and communities that are represented within the videos. Given the centrality of the empowerment of women within their empowerment discourse, the analysis will consider the empowered female farmer in particular and how they empirically experience empowerment.

Unilever produces a myriad of positive farmer images to communicate its empowerment strategy, focusing on groups and using illustrative personal examples. The representations tend toward the idealized, with farmers appearing to be at one with their agrarian communities and the agricultural landscapes that envelop these. There is a tendency toward a caricature-like representation of the 'happy' farmers, which is often 
supported with over-enthusiasm in speech or body language e.g. unfaltering constant smiling farmers (Figure 5).
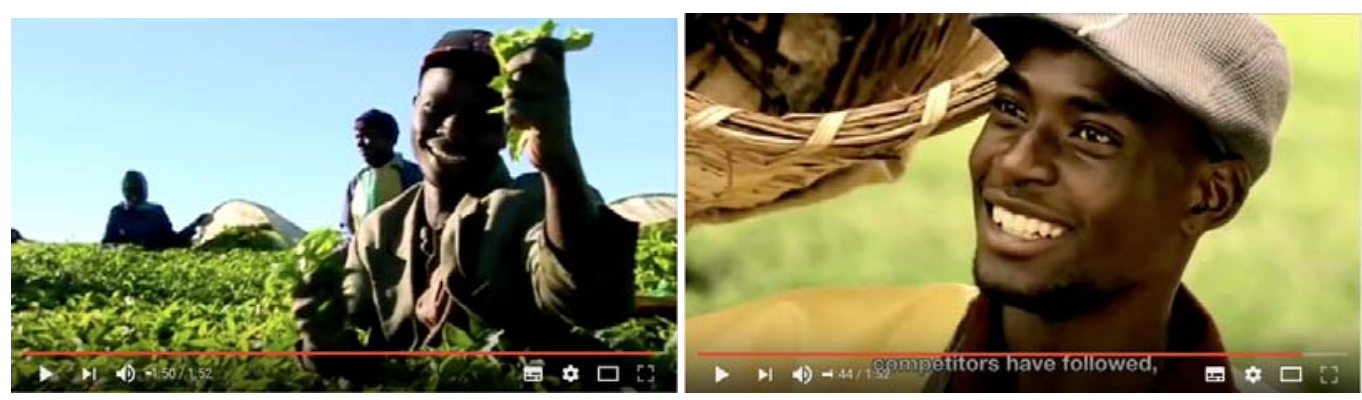

Figure 5. Images from V4: The happy farmer?

The source of the happiness is generally dependent on the quality of their product, which in turn appears to mirror quality of life. Interestingly, the fact that this framing of happiness around farming is reductionist is highlighted in one of the videos where Christine, a vanilla farmer, is interviewed and asks whether the interviewer is asking about what makes her happy in relation to vanilla or in general (V2).

Evidence exists of how these representations are crafted and the use of editing in the videos provide multiple representations of the same farmer e.g. 'Christine the Vanilla farmer' is presented in four videos, V2, V5, V9 (briefly) and V15 illustrating the different metaphors of the empowered female and the empowered farmer. Another example of reality crafting is the constant representations of the close proximity of 
supplier and Unilever (and their chefs). Evoking reality crafting techniques for a caring façade, the chefs choose the farmers produce due to its high quality much to the farmers delight, the focus is really on consumers, sustaining a Unilever centric view: "Any farmer that knows his produces are going to be consumed all over the world, with the quality we create, well, would feel really proud. A farmer can't ask for anything more than that" (Antonio Tienza, Knorr Farmer: V13). The tendency is to highlight central achievements 'with' farmers, which gives a sense of co-creation rather than imposition of the sustainability agenda, presenting Unilever and its partners in a favorable light. This contrasts with the images and lack of farmers' own voice, which indicate that they are more the recipients of expectations than co-creators.

There is a suggestion within the videos that some of the farmers may not be as happy as they appear and that some the farmers' livelihoods are unsustainable, which in turn raises questions about the feasibility of Unilever's sustainability imaginary. There are hints that the incomes that the farmers' are getting may not be enough to support them. One female gherkin farmer mentions that she is in need of finance and "wants a better life" (V7). Another example of this is Christine, a vanilla farmer from Madagascar, who expresses two desires that undermine the imaginary presented. First, while acknowledging the good work that Unilever and its supplier Symrise have done for her community, she believes that more needs to be done. 
“I'm asking to keep getting support...I'm asking this to Symrise on behalf of the whole group and not just me. They're already doing a lot but we need more help" (V2).

Christine appears to be adopting the position of a supplicant here, which undermines the idea of empowerment. Second, she states that she does not want her children to become vanilla farmers and instead wants them to become doctors. There are clear indications that the videos are being edited to mask the harsh realities that the farmers are facing. In several of the videos there are subtitles to convey what the farmers, often female, are saying. In an attempt to explore whether the subtitles did justice to what was actually being said, we obtained a professional translation for V2 from Malagasy to English. Some of the most problematic excerpts are presented in Table 1, showing how the editing of the videos is part of a process of decontextualization whereby important details about the local context are omitted from the subtitles (i.e. watching the crops throughout the night) and terms are substituted (i.e. life vs. livelihood). These edits do impact the message and imaginary being conveyed to the audience.

Table 1. Evidence of decontextualization through editing of subtitles

\begin{tabular}{|l|l|l|}
\hline Video & V2: Christine, a vanilla farmer from Madagascar (Unilever, 02/02/2015) \\
\hline $\begin{array}{l}\text { Question posed by } \\
\text { interviewer }\end{array}$ & What challenges do you face? & What are your aspirations for the future? \\
\hline
\end{tabular}




\begin{tabular}{|l|l|l|}
\hline $\begin{array}{l}\text { Subtitles provided by } \\
\text { Unilever }\end{array}$ & $\begin{array}{l}\text { We don't really have a problem with vanilla } \\
\text { farming. After flowering and pollination, there } \\
\text { is the problem of theft. We have to work } \\
\text { together as a community to protect the farms. } \\
\text { That's the problem with vanilla. }\end{array}$ & $\begin{array}{l}\text { My aspirations for the future are that the } \\
\text { price of vanilla will increase. Apart from } \\
\text { the price of vanilla, my aspirations are that } \\
\text { people will continue to work with } \\
\text { Symrise because it improves our } \\
\text { livelihoods. }\end{array}$ \\
\hline $\begin{array}{l}\text { Translation of what is } \\
\text { being said }\end{array}$ & $\begin{array}{l}\text { The problems we have here concerning } \\
\text { vanilla there are that many about the work, } \\
\text { but after it has finished flowering it and there } \\
\text { are pods, there are still some thieves while there } \\
\text { is ripe vanilla. }\end{array}$ & $\begin{array}{l}\text { What I hope for.... just concerning } \\
\text { vanilla, I still hope now that the price of } \\
\text { vanilla keeps rising. That there will still be } \\
\text { a good market for it, and then the income } \\
\text { for us in the countryside will come. } \\
\text { awn looking after our ripening vanilla, so that } \\
\text { it won't be stolen. }\end{array}$ \\
$\begin{array}{l}\text { So those are our problems still here concerning } \\
\text { vanilla. }\end{array}$ & $\begin{array}{l}\text { Our hope is, we like to hope.... The vanilla, } \\
\text { I'd like it to be expensive to buy, and after } \\
\text { that I hope that we can trust in working } \\
\text { together with Symrise, I can see that that } \\
\text { helps improve our life here. }\end{array}$ \\
\hline
\end{tabular}

Empowerment and gender. The main group that has been identified by Unilever as beneficiaries of their empowerment is women. An instrumental logic is adopted in which Unilever targets women, as it is believed that their empowerment will help Unilever to achieve its higher-level sustainability goal of poverty reduction, which is itself necessary for Unilever to achieve its commercial goals. Women have little agency in the processes being described. Instead, the processes 'empowering' women are constructed, initiated and managed by Unilever and its partners (suppliers and NGOs). The discourse presented in the videos does not challenge gendered power relations nor does it confront issues related to local gendered division of labour, echoing findings from previous research on GVCs (Prieto-Carron, 2008; Tallontire et al., 2005). Unilever's apparent instrumental empowerment of women in its agricultural supply 
chains may in fact reinforce pre-existing gender inequalities (Loconto, 2015; Wilson, 2011) by confining women to inferior positions of family labourer and field workers, which result from deeply embedded structural issues such as land ownership traditions and gendered roles.

The video on gherkin production in India (V7) uses a number of buzzwords related to empowerment, such as increasing the role of women in decision-making. It is interesting that Unilever choose to empower them first in terms of familial institutions (e.g. women appear to be making decisions relating to nutrition i.e. shopping and cooking) and laterally financially (in terms of borrowing), rather than in terms of the agrarian purpose upon which the relationship is constructed. In V3 a Unilever account manager from Kenya speaks to the video which focuses heavily on training and educating particularly female farmers on fundamentals such as nutrition and hygiene: "it's simple...if a farmer and their family is healthy and sick less often it means they really can reach their full potential. They can live a wholesome and productive life and go on to nurture the next generation of happy and healthy farmers. So it's a bright future for Unilever and the farmers, everyone wins".

It seems to fix them in their reproductive positions of wives and mothers rather than self-determining subjects and in productive work. Unilever sustainability imaginary for women farmers perpetrates "deeply embedded gender production relations in which 
women are deemed to play a subordinate role in agriculture" (Barrientos, 2014: : 792) and remain primarily constructed through their unpaid family and reproductive roles.

Gendered representations feature strongly in the videos within and across contexts. Women are represented as 'western' or 'non-western', the western women being presented as an empowering consumer or a white-collar employee. This provides stark contrast to the typically black farming woman. They are presented as having commonality in terms of their desire to look after family and the community. This again echoes previous research that has shown how commercial values chains reflect societal norms of gendered patterns of consumption and production (Barrientos 2014) (e.g. V7, V10, V11).

In the male roles, the power is dynamic and changes in relation to women but also relative to other males. This is particularly obvious in terms of hierarchy and reinforced in the Western and non-Western divides. In this context the role of dress and imagery is very important. This is reinforced in the contrasting images of those shown farming and those at the farming summit (V1). They are often discussed by those in more senior and less land-orientated positions (V2, V16, V17, V18). Often the clothing can be depicted on a westernized continuum, which reflects the hierarchy congruently, higher roles and status being reflected in the more westernized dress. There is a related construction evidenced in the females represented also, those who work in the farms appear in 
traditional dress, they often use pink buckets and generally are re-positioned inside the home at some point during most videos (V3).

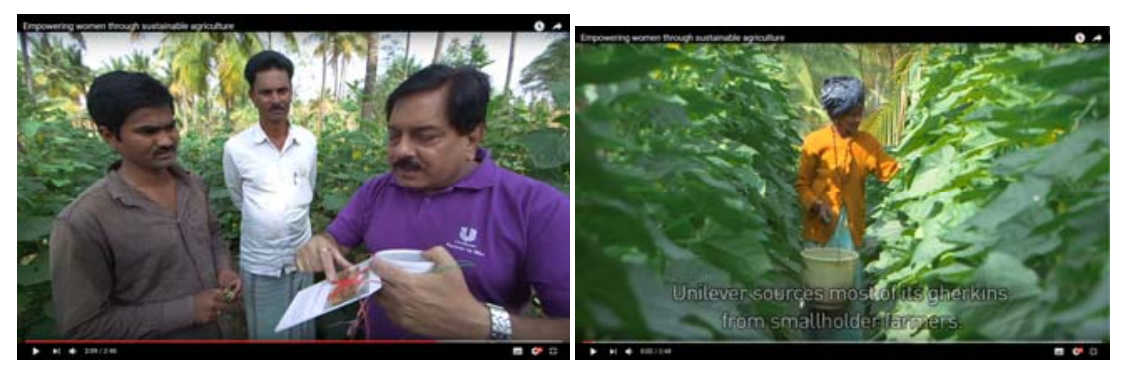

Figure 6. Images from video 7 - Women workers, Men trainers

Table 2 below shows how the multimodal CDA was conducted using the example of V7. This illustrates how elements such as the total time individuals speak, the visual and kinetic features and the spoken and written speech all contribute to perpetrating traditional gendered roles between male and female protagonists. There is an irony to the consistent condescending manner in Unilever's male representatives' discourse around 'voice-giving' to women. Both males who speak get names and roles assigned to them. Females do not get names and locations except for the singular female farmer whose literal voice is heard and is focused on finance, debt and survival. 
Table 2. Multimodal analysis of Video 7 'Empowering women through sustainable agriculture' (Unilever YouTube video, published on 19 October 2015)

\begin{tabular}{|c|c|c|c|c|}
\hline Theme(s) & \multicolumn{4}{|c|}{ Women, voice and empowerment, sustainable agriculture, training } \\
\hline Supply chain & \multicolumn{4}{|l|}{ Gherkin } \\
\hline Protagonists in video & \multicolumn{4}{|c|}{$\begin{array}{l}11 \text { people featuring in the video - * indicates those who speak } \\
\text { - } \quad \text { * Boris Rafalski, Procurement director Sustainable sourcing (speaks } 1 \text { min } 30 \text { sec in total) } \\
\text { - } \quad \text { A woman wearing an orange top, picking gherkins, nameless } \\
\text { - } \quad \text { Two women cooking in two separate kitchens, one grinding cereals/spices and the other making bread, nameless } \\
\text { - Three men in the gherkin field: one wearing a purple Unilever polo-shirt (appears to be a trainer), two men listening (appear to be } \\
\text { - } \quad \text { Two women picking gherkins, nameless } \\
\text { - } \quad \text { * Mr. G.M. Vinod, Owner and Partner, Barakhi Associates, Barnataka (speaks } 34 \text { sec in total) } \\
\text { - } \quad \text { * Mrs. Radamma, Hassan, Kanataka - shown picking gherkins throughout the video (speaks } 26 \text { sec in total) }\end{array}$} \\
\hline \multicolumn{5}{|l|}{ Frames } \\
\hline Minute & $0 \cdot 18$ & 0.30 & 0.43 & $2 \cdot 1$ \\
\hline \multicolumn{5}{|c|}{$\begin{array}{lll}\text { Visual and } & \text { kinetic } \\
\text { aspects } & & \\
\end{array}$} \\
\hline Landscape/context & $\begin{array}{l}\text { Gherkin plants cover the } \\
\text { background, vivid green colour }\end{array}$ & $\begin{array}{l}\text { Gherkin plants on both sides of the } \\
\text { frame, vivid green colour }\end{array}$ & $\begin{array}{l}\text { Inside house, possibly kitchen, } \\
\text { table, pestle mortar }\end{array}$ & $\begin{array}{l}\text { Gherkin plants cover the } \\
\text { background, vivid green leaves } \\
\text { and yellow flowers }\end{array}$ \\
\hline People's appearance & Boris wearing a dark shirt & $\begin{array}{l}\text { Woman wearing bright coloured } \\
\text { clothes, head covered and holding a } \\
\text { bucket }\end{array}$ & $\begin{array}{l}\text { Woman wearing dark clothes, } \\
\text { head uncovered }\end{array}$ & $\begin{array}{l}\text { Mrs. Radamma wearing shirt - } \\
\text { work clothes, head uncovered } \\
\text { when she speaks }\end{array}$ \\
\hline People's actions & $\begin{array}{l}\text { Boris standing in the field, } \\
\text { speaking in English }\end{array}$ & $\begin{array}{l}\text { Woman picking gherkins, repetitive } \\
\text { movement, walking through the } \\
\text { field }\end{array}$ & $\begin{array}{l}\text { Woman grinding cereals/spices in } \\
\text { a repetitive movement }\end{array}$ & $\begin{array}{l}\text { Mrs. Radamma standing in the } \\
\text { field, speaking in her native } \\
\text { language and alternatively picking }\end{array}$ \\
\hline
\end{tabular}




\begin{tabular}{|c|c|c|c|c|}
\hline & & & & gherkins \\
\hline Postures and gestures & $\begin{array}{l}\text { Boris standing fairly still, looking } \\
\text { directly at the camera }\end{array}$ & $\begin{array}{l}\text { Woman, slightly bended, picking } \\
\text { with one hand, holding bucket in } \\
\text { other, not looking at the camera }\end{array}$ & $\begin{array}{l}\text { Woman kneeling on the floor, } \\
\text { using a her hands for grinding, not } \\
\text { looking at the camera }\end{array}$ & $\begin{array}{l}\text { Mrs. Radamma standing fairly } \\
\text { still, looking directly at the } \\
\text { camera }\end{array}$ \\
\hline \multicolumn{5}{|l|}{ Speech } \\
\hline Who is speaking? & Boris Rafalski & Boris Rafalski & Boris Rafalski & Mrs. Radamma \\
\hline What is said? & $\begin{array}{l}\text { "Women play a key role in } \\
\text { agriculture, we want to focus on } \\
\text { women in our programs" }\end{array}$ & $\begin{array}{l}\text { "It's important to give } \\
\text { women a voice and to empower } \\
\text { them to take a more active part in } \\
\text { the decision-making that is } \\
\text { affecting the entire family" }\end{array}$ & $\begin{array}{l}\text { "For our nutrition program } \\
\text { women are key because women } \\
\text { are the ones that take the lead in } \\
\text { this in deciding on nutrition for } \\
\text { their family and therefore we } \\
\text { want to empower them through } \\
\text { the training we are doing" }\end{array}$ & $\begin{array}{l}\text { "We want to work to earn money, } \\
\text { we can survive if we do this. We } \\
\text { have a women's association in the } \\
\text { village. From that we take loans } \\
\text { and we repay them in } \\
\text { instalments" }\end{array}$ \\
\hline Text & $\begin{array}{l}\text { Name and position of Boris } \\
\text { Rafalski }\end{array}$ & - & - & $\begin{array}{l}\text { Subtitles for translating what Mrs. } \\
\text { Radamma says }\end{array}$ \\
\hline Themes & $\begin{array}{l}\text { Women's role and place, } \\
\text { agriculture }\end{array}$ & $\begin{array}{l}\text { Women, voice and empowerment, } \\
\text { family }\end{array}$ & $\begin{array}{l}\text { Women, nutrition, feeding family, } \\
\text { empowerment, decision }\end{array}$ & $\begin{array}{l}\text { Work, finance/earnings, survival, } \\
\text { loans/debt }\end{array}$ \\
\hline
\end{tabular}




\section{Discussion}

We explore in more depth what our findings suggest about underlying mechanisms of power and marginalization at different for this group. We are particularly interested in what is absent from the discourse in trying to unveil underlying structures (Wood and Kroger, 2000).

\section{Macro-level: Inequalities and trickle-down economics}

The macro level of the political economy and the globalized system of agricultural production are not explicitly referred to within the videos. These have to go unnamed as naming them would reveal the exploitative social relations that these structures have created and call into question Unilever's claims about the sustainability of its supply chain strategies. The decontextualization of the farmers' poverty is necessary for Unilever's sustainable farming imaginary to be presented as feasible. While the farmers from emerging markets are growing cash crops to be consumed by Unilever's richer customers, many of the farmers and their families presented in the videos are struggling with their own nutrition.

This corroborates research on GVC (Gereffi, 1994; Barrientos et al., 2016) highlighting the importance of governance structures, in terms of power relations, of such chains and the institutional contexts in which they are embedded at local, national and international levels. Value chains in various sectors, and food in particular, have become governed 
around the interests of a few large players, such as retailers and manufacturers, has received much attention (Palpacuer et al., 2005; Thompson and Scoones, 2009). Tregear et al. (2016: 436) explain how as a result of the dynamics of GVCs "small-scale suppliers in the global agro-food sector become excluded or marginalized from value chains, as they become 'captured', or transactionally dependent on larger, more powerful buyers."

These underlying GVC dynamics cannot be presented in the videos without undermining the imaginary of sustainability. The effectiveness of private and marketdriven sustainability initiatives, primarily in the form of standards, in driving real change for those most affected (i.e. farmers and workers upstream) has been questioned (Loconto, 2015; Tallontire et al., 2005; Prieto-Carron, 2008). These initiatives are part of the governance of GVCs and reinforce already existing stringent conditions imposed by dominant buyers over their suppliers, such as "meeting high production standards, accepting falling competitive market prices, and working to tight 'just-in-time' production schedules" (Barrientos et al., 2003: 1522). In many of the videos these strict requirements do transpire and particularly around the concept of quality, which is a core dimension to Unilever's farming sustainability discourse. This is where the instrumentalism of the sustainability imaginary constructed by Unilever takes its full meaning.

\section{Meso-level: Supply chain capitalism and inter-organizational dependence}


Our findings suggest some interesting paradoxical rhetoric and representations. We are seeing 'normalization' of the discourse around farmers. The sustainability imaginary for farmers as constructed by Unilever relies on the perpetration of colonial relationships of exploitation and power structures, but presents this as unproblematic and beneficial for all (Maguire and Hardy, 2009). Unilever tends toward a relative view of the farmer in terms that their existence is generally discussed in terms of resilience and benefit for Unilever and Unilever's future as well as their customers. The farmers have little prominence, centrality or voice and may be subject to reification.

There are striking continuities with the colonial discourse, through the use of racialized imagery and the idea that farmers in the global supply chains are "objects" of sustainable development by the Western "expert” (Özkazanç-Pan, 2008; Wilson, 2011). The visuals of lush nature and beautiful products contribute to postcolonialism, as the colonies were the sources of exotic sought-after products for the "motherland".

In contrast to the claims made by Unilever in its videos, there is undeniable evidence from a few female farmers that price premiums are at a minimum and other issues such as debt are not being presented. The situation is rather dire in some of the contexts depicted as fairly idyllic. In an article published in the Guardian in 2016 (Griffiths and Ghouri, 2016), a vanilla farmer Francis Falihari mentions how 'it is impossible to survive from growing vanilla alone if you are small farmers like us' and he blames the large companies for having a detrimental role that forces farmers to change their 
practices and prematurely cut their crops in order for supply to be secured. Unilever's sustainability strategy is motivated by continuity of supply, i.e. securing the continued overconsumption in developed economies, rather than sustainable development. Our findings therefore echo previous research (Nelson and Tallontire, 2014) that has identified 'Global Sourcing' as the dominant narrative related to sustainability.

The operational aspects of SCM, such as contracts and pricing, are absent from the videos, which actually signals that these are significant underlying mechanisms in shaping the social relations and practices. As noted in previous research (Vincent, 2005; Touboulic et al., 2014), the outcomes of supply chain exchanges and who they benefit cannot be fully grasped without a consideration for the resource dependency, and therefore the power relations, between the different parties. The representations of farmers' compliance to Unilever's sustainability agenda and the actual solutions and initiatives implemented by Unilever in their supply chain are therefore considerably determined by the imbalanced dependency that exists between Unilever and the farmers.

\section{Micro level: Instrumental empowerment and the absence of voice and agency}

Although farmers have not become de-realized as victims, much of their singular identity has been lost and their voices are being subsumed (Butler, 2009). The validity of their speech, the institutional knowledge they may have is being threatened and their voices are being de-legitimatized to the point where 'consumers/viewers' no longer 
expect their voices to be heard. In this sense, our findings align with postcolonial work in showing that positive representations of postcolonial marginalized subjects, here around sustainability, contribute to rendering the possibility to challenge neoliberal models, here exemplified by the global supply chain, unconceivable, invisible and even unnecessary (Wilson, 2011). Within Unilever's imaginary the supplier voice on sustainability is marginalized through impersonal, patronizing and colonial representations. Yet their representations are framed within the discourse of empowerment.

Empowerment is defined as a "mechanism by which people, organizations, and communities gain mastery over their affairs" (Rappaport, 1987: 122). The concept of empowerment however is closely connected to other concepts such as freedom and emancipation, which strongly emphasize agency. Emancipation is the "process through which individuals and groups become freed from repressive social and ideological conditions, in particular those that place socially unnecessary restrictions upon the development and articulation of human consciousness" (Alvesson and Willmott, 1992: 432). Freedom can be defined as "the state which allows the person to remove himself (sic) from those dominating situations that make him simply a reacting object" (Blauner, 1964: 16). This type of freedom is known as 'positive freedom', also known as 'freedom to' and is contrasted with 'freedom from' or 'negative freedom', which is focused on removing the external constraints on freedom, such as poverty (Varman and 
Vikas, 2007). While the latter is important, it cannot lead to positive freedom and is thus a limited form of emancipation.

In our analysis, Unilever's empowerment strategy is focused on negative freedom and only to the extent that it is consistent with their commercial objectives. But by only being able to offer farmers freedom from some of the worst excesses of poverty by integrating them more closely within their supply chains, Unilever is increasing the farmers dependence upon a powerful multinational company and is thus undermining the negative freedom of its farmers. Interestingly, positive freedom for some farmers may mean escaping from these supply chains. Christine, a vanilla farmer, wants positive freedom for her children and she is very clear that this means a future for them outside of vanilla farming (V2).

The construction of the female farmer subject position in Unilever's imaginary reproduces the "structural and relational constraints (...) that limit women's voices and participation" (Loconto, 2015: 194) and hence they "fail to deal with deeply embedded structures of inequality, such as low wages and the segmentation of women into the lowest paid and more insecure jobs" (Prieto-Carron, 2008: 13). Instead there is very much a sense that the sustainability imaginary for women farmers is that of female postcolonial subjects doubly subjugated by the colonizer, Unilever in this case, and indigenous patriarchy (Spivak, 1988; Özkazanç-Pan, 2008). 
The possibilities for real emancipation for the farmers requires considering them as subjects and giving them a voice because "emancipation is not a gift bestowed on people" (Huault et al., 2014: 25). Two pertinent questions can therefore be posed: (1) How may farmers remove themselves from this dominating situation where they are made reacting objects? (2) Given a voice how would the farmers envision themselves outside a destiny of continuous exploitation? These questions could be the fruitful basis for future research where an attempt is made at "letting the people speak for themselves" (Alvesson and Willmott, 1992: 111).

\section{Conclusion}

This article engages with the social and political aspects of sustainable SCM, which has so far tended to treat the transition to more ecologically resilient and socially equitable supply chains as a technological and rational problem. Our analysis of Unilever's sustainability imaginary for smallholder farmers is a first step towards understanding the way in which the dominant discourse creates limitations in terms of what is possible and imaginable for the broader sustainability agenda in supply chains dominated by large corporations. Utilizing processes of decontextualization, through which underlying structures are removed, is a way to construct corporation-led instrumental subject positions of empowered farmers for sustainability in supply chains. The lack of alternative imaginaries restricts what we conceive as possible solutions and enslaves us to a single exploitative vision for sustainability. The videos are accounts of what 
initiatives are imposed on the farmers rather than how they truly experience them. Unilever through their editing of the videos are crafting the supply chain, sustainability and the notion of empowerment. If we accept that these videos are created for PR purposes and therefore represent Unilever's version of best practice, then we take the view that this version of "best" is not good enough. In fact, our study contributes the development of a concept of "instrumental empowerment" as a new way of exploring the discourses of the powerful and interrogating corporate sustainability.

The scope of this study enables us to explore the construction of the dominant sustainability imaginary and unveiling the underlying dynamics of the marginalization of farmers around sustainability in corporate supply chains. However, our interrogation around power and marginalization has highlighted the need to explore the possibilities for real emancipation. We follow Rappaport in suggesting that as researchers "perhaps we will also learn to listen to the voice of the people with whom we work so as to allow them to tell us what it means to be empowered in their particular context. The narrative approach suggests new ways to become more sensitive to such voices" (Rappaport, 1995: 798-799).

We suggest that much more empirical evidence is needed to extend our understanding of what real emancipation would entail when placing marginalized groups in supply chains such as farmers as subjects. Such research would be in line with a view of emancipation that asserts equality, rather than assumes that in order to be emancipated 
the marginalized need to be enlightened about their condition (Huault et al., 2014). We envision that such research endeavours would actively seek to give voice to the marginalized. Methodologies such as participatory approaches (Tallontire et al., 2005; Reason and Heron, 1986) can help put the interests and concerns of marginalized stakeholders at the heart of the research process. We contend that researchers have an active role to play in supporting the realization of such emancipation. 


\section{References}

Alvesson M and Willmott H. (1992) On the idea of emancipation in management and organization studies. Academy of management review 17: 432-464.

Banerjee SB. (2008) Corporate social responsibility: The good, the bad and the ugly. Critical sociology 34: 51-79.

Barrientos S. (2014) Gendered global production networks: Analysis of cocoa, Äìchocolate sourcing. Regional Studies 48: 791-803.

Barrientos S, Dolan C and Tallontire A. (2003) A gendered value chain approach to codes of conduct in African horticulture. World Development 31: 1511-1526.

Barrientos S, Gereffi G and Pickles J. (2016) New dynamics of upgrading in global value chains: Shifting terrain for suppliers and workers in the global south. SAGE Publications Sage UK: London, England.

Barros M. (2014) Tools of Legitimacy: The Case of the Petrobras Corporate Blog. Organization Studies 35: 1211-1230.

Blauner R. (1964) Alienation and freedom: The factory worker and his industry, Chicago: The University of Chicago Press.

Blowfield M and Frynas JG. (2005) Editorial Setting new agendas: critical perspectives on Corporate Social Responsibility in the developing world. International Affairs 81: 499-513.

Boiral O. (2013) Sustainability reports as simulacra? A counter-account of A and A 1 GRI reports. Accounting, Auditing \& Accountability Journal 26: 1036-1071.

Burn-Callander R. (2015) Unilever boss Paul Polman slams capitalist obsession with profit. The Telegraph.

Butler J. (2009) Frames of War: The Politics of Ungreivable Life. Humanities and Arts Research Centre of Royal Holloway, the School of Psychosocial Studies (Birkbeck), and the Birkbeck Institute for Social Research 4.

Castoriadis C. (1997) The imaginary institution of society: Mit Press.

Unilever YouTube channel. (2017) Available at: https://www.youtube.com/user/Unilever.

Conger JA and Kanungo RN. (1988) The empowerment process: Integrating theory and practice. Academy of Management Review 13: 471-482.

Fairclough N. (2005) Peripheral vision: Discourse analysis in organization studies: The case for critical realism. Organization Studies 26: 915-939.

Fairclough N. (2009) A dialectical-relational approach to critical discourse analysis in social research. Methods of critical discourse analysis 2: 162-187.

Fletcher AJ. (2017) Applying critical realism in qualitative research: methodology meets method. International Journal of Social Research Methodology 20: 181194. 
Foucault M. (2002) Power (Essential Works of Foucault, 1954-1984, Vol. 3), London: Penguin.

Garland J, Huising R and Struben J. (2013) "What if technology worked in harmony with nature?" Imagining climate change through Prius advertisements. Organization 20: 679-704.

George G, Howard-Grenville J, Joshi A, et al. (2016) Understanding and tackling societal grand challenges through management research. Academy of Management Journal 59: 1880-1895.

Gereffi G. (1994) Capitalism, development and global commodity chain. In: Sklair L (ed) Capitalism and Development. London: Routledge, 211-231.

Griffiths M and Ghouri N. (2016) Madagascar's vanilla farmers face volatile times after poor harvest. The Guardian.

Hajer MA. (1995) The politics of environmental discourse: ecological modernization and the policy process: Clarendon Press Oxford.

Henson S and Humphrey J. (2010) Understanding the complexities of private standards in global agri-food chains as they impact developing countries. Journal of Development Studies 46: 1628-1646.

Huault I, Perret V and Spicer A. (2014) Beyond macro-and micro-emancipation: Rethinking emancipation in organization studies. Organization 21: 22-49.

Leca B and Naccache P. (2006) A critical realist approach to institutional entrepreneurship. Organization 13: 627-651.

Levy DL and Spicer A. (2013) Contested imaginaries and the cultural political economy of climate change. Organization 20: 659-678.

Loconto A. (2015) Can certified-tea value chains deliver gender equality in Tanzania? Feminist Economics 21: 191-215.

Maguire S and Hardy C. (2009) Discourse and deinstitutionalization: The decline of DDT. Academy of management journal 52: 148-178.

Matthews L, Power D, Touboulic A, et al. (2016) Building Bridges: Towards Alternative Theory of Sustainable Supply Chain Management. Journal of Supply Chain Management 52.

Mauthner NS and Doucet A. (2003) Reflexive accounts and accounts of reflexivity in qualitative data analysis. Sociology 37: 413-431.

Mohrman SA and Worley CG. (2010) The organizational sustainability journey. Organizational Dynamics 39: 289-294.

Montabon F, Pagell M and Wu Z. (2016) Making sustainability sustainable. Journal of Supply Chain Management.

Nelson V and Tallontire A. (2014) Battlefields of ideas: Changing narratives and power dynamics in private standards in global agricultural value chains. Agriculture and Human Values 31: 481-497. 
Nestlé. (2015) Nestlé makes progress on empowering women in cocoa supply chain. Available at: http://www.nestle.com/media/news/nestle-empowers-women-incocoa-supply-chain-update.

O'Halloran KL. (2011) Multimodal discourse analysis. In: Hyland K and Paltridge B (eds) Bloomsbury companion to discourse analysis. A\&C Black.

Oxfam. (2013) Behind the Brands methodology summary.

Oxfam. (2016) Behind the brands. Available at: https://www.behindthebrands.org/company-scorecard.

Özkazanç-Pan B. (2008) International management research meets "the rest of the world". Academy of management review 33: 964-974.

Palpacuer F, Gibbon P and Thomsen L. (2005) New Challenges for Developing Country Suppliers in Global Clothing Chains: A Comparative European Perspective. World Development 33: 409-430.

Phillips N and Hardy C. (2002) Discourse analysis: Investigation processes of social construction, Thousand Oaks CA: Sage.

Phillips N, Sewell G and Jaynes S. (2008) Applying Critical Discourse Analysis in Strategic Management Research. Organization Research Methods 11: 770-789.

Prasad A. (2003) Postcolonial theory and organizational analysis: A critical engagement: Springer.

Prieto-Carron M. (2006) Corporate social responsibility in Latin America: Chiquita, women banana workers and structural inequalities. Journal of Corporate Citizenship 21: 1-10.

Prieto-Carron M. (2008) Women workers, industrialization, global supply chains and corporate codes of conduct. Journal of Business Ethics 83: 5.

Rappaport J. (1987) Terms of empowerment/exemplars of prevention: Toward a theory for community psychology. American Journal of community psychology 15: 121-148.

Rappaport J. (1995) Empowerment meets narrative: Listening to stories and creating settings. American Journal of community psychology 23: 795-807.

Reason P and Heron J. (1986) Research with people: The paradigm of cooperative experiential inquiry. Person-Centered Review 1: 456-476.

Ruddick G. (2016) Unilever CEO Paul Polman - the optimistic pessimist The Guardian.

Said E. (1979) Orientalism. 1978. New York: Vintage 199.

Sims-Schouten W, Riley SC and Willig C. (2007) Critical realism in discourse analysis: A presentation of a systematic method of analysis using women's talk of motherhood, childcare and female employment as an example. Theory \& Psychology 17: 101-124.

Spivak GC. (1988) Can the subaltern speak? Can the subaltern speak? Reflections on the history of an idea: 21-78. 
Tallontire A, Dolan C, Smith S, et al. (2005) Reaching the marginalised? Gender value chains and ethical trade in African horticulture. Development in practice 15: 559-571.

Thompson J and Scoones I. (2009) Addressing the dynamics of agri-food systems: an emerging agenda for social science research. Environmental Science \& Policy 12: 386-397.

Touboulic A, Chicksand D and Walker H. (2014) Managing imbalanced supply chain relationships for sustainability: A power perspective Decision Sciences 45: 577619.

Tregear A, Trörök Å and Gorton M. (2016) Geographical indications and upgrading of small-scale producers in global agro-food chains: A case study of the Mak $\sqrt{\geq}$ Onion Protected Designation of Origin. Environment and Planning A 48: 433451.

Tsing A. (2009) Supply chains and the human condition. Rethinking Marxism 21: 148176.

Unilever. (2015) Mobilising collective action - Unilever sustainable living plan summary of progress 2015. Rotterdam, NL.

Unilever. (2017) Who we are. Available at: www.unilever.co.uk/about/who-we-are/.

Vaara E and Tienari J. (2008) A discursive perspective on legitimation strategies in multinational corporations Academy of management review 33: 985-993.

Varman R and Vikas RM. (2007) Freedom and consumption: Toward conceptualizing systemic constraints for subaltern consumers in a capitalist society. Consumption, Markets and Culture 10: 117-131.

Vincent S. (2005) Really dealing a critical perspective on inter-organizational exchange networks. Work, Employment \& Society 19: 47-65.

Welford RJ. (1998) Corporate environmental management, technology and sustainable development: postmodern perspectives and the need for a critical research agenda. Business Strategy and the Environment 7: 1-12.

Wilson K. (2011) 'Race', Gender and Neoliberalism: changing visual representations in development. Third World Quarterly 32: 315-331.

Wood LA and Kroger RO. (2000) Doing discourse analysis: Methods for studying action in talk and text: Sage.

Wright C, Nyberg D, De Cock C, et al. (2013) Future imaginings: organizing in response to climate change. Organization 20: 647-658.

Young LM and Hobbs JE. (2002) Vertical linkages in agri-food chains: Changing roles for producers, commodity groups, and government policy. Review of Agricultural Economics 24: 428-441. 


\section{Appendix 1. Videos analyzed in the study}

\begin{tabular}{|c|c|c|c|c|c|c|}
\hline & Title of video & Who features? & Supply chain & Publication & $\begin{array}{l}\text { Views pre-study } \\
\text { (November 2016) }\end{array}$ & Link to video \\
\hline V1 & Knorr Farmer Summit 2015 & $\begin{array}{l}\text { Unilever, farmers and suppliers } \\
\text { and key partners }\end{array}$ & $\begin{array}{l}\text { Knorr food supply } \\
\text { chain }\end{array}$ & $\begin{array}{l}\text { Unilever } \\
07 / 10 / 2015\end{array}$ & 301 & $\begin{array}{l}\text { https: } / / \text { www.youtube } . c o m / \text { watch} ? \mathrm{v}=\mathrm{aKsNzT} 84 \\
\text { Jpo\&t }=85 \mathrm{~s}\end{array}$ \\
\hline $\mathrm{V} 2$ & $\begin{array}{l}\text { Christine, a vanilla farmer from } \\
\text { Madagascar }\end{array}$ & Vanilla Farmers, Symrise & Vanilla & $\begin{array}{l}\text { Unilever } \\
02 / 02 / 2015\end{array}$ & 210 & $\begin{array}{l}\text { https://www.youtube.com/watch?v=31-- } \\
\underline{\text { UrvxzNk\&t=10s }}\end{array}$ \\
\hline $\mathrm{V} 3$ & $\begin{array}{l}\text { Building a bright future for our } \\
\text { smallholder farmers }\end{array}$ & $\begin{array}{l}\text { Elizabeth, Kenya, accountant for } \\
\text { Unilever } \\
\text { Unilever and GAIN (the global } \\
\text { alliance for improved nutrition) } \\
\text { and Marcatus QED }\end{array}$ & Tea & $\begin{array}{l}\text { Unilever } \\
28 / 10 / 2015\end{array}$ & 4043 & $\begin{array}{l}\underline{\mathrm{https}: / / w w w . y o u t u b e \cdot c o m / w a t c h ? v=W f z X z 8 \mathrm{kj}} \\
\underline{\mathrm{M} 7 \mathrm{Y}}\end{array}$ \\
\hline V4 & Sustainable tea farming & $\begin{array}{l}\text { Lipton Rainforest alliance, } \\
\text { smallholder farmers }\end{array}$ & Tea & $\begin{array}{l}\text { Unilever } \\
25 / 05 / 2012\end{array}$ & 1954 & $\begin{array}{l}\text { https://www.youtube.com/watch?v=fi- } \\
\text { pC6kCvhk }\end{array}$ \\
\hline V5 & $\begin{array}{l}\text { Working with smallholder } \\
\text { farmers }\end{array}$ & Unilever & Tea & $\begin{array}{l}\text { Unilever } \\
15 / 04 / 2014\end{array}$ & 1884 & $\begin{array}{l}\text { https://www.youtube.com/watch?v=Y 531US } \\
\text { GMYE }\end{array}$ \\
\hline V6 & Kenya tea development agency & 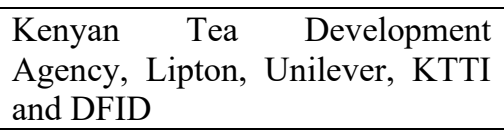 & Tea & $\begin{array}{l}\text { Unilever } \\
02 / 02 / 2015\end{array}$ & 380 & $\begin{array}{l}\text { https://www.youtube.com/watch?v=OdntnangI } \\
\underline{\mathrm{dM}}\end{array}$ \\
\hline V7 & $\begin{array}{l}\text { Empowering women through } \\
\text { sustainable agriculture }\end{array}$ & $\begin{array}{ll}\text { Women } & \text { farmers, Unilever } \\
\text { employees. } & \text { Bharathi Associates }\end{array}$ & Gherkins & $\begin{array}{l}\text { Unilever } \\
19 / 10 / 2015\end{array}$ & 1092 & $\begin{array}{l}\text { https://www.youtube.com/watch? } \mathrm{v}=3 \mathrm{Rsy} 6 \text { srJ } \\
\underline{\mathrm{ww}}\end{array}$ \\
\hline V8 & $\begin{array}{lrr}\text { Sunrise }- & \text { Bringing together } \\
\text { Sustainable } & \text { Sourcing and } \\
\text { Development } & & \end{array}$ & $\begin{array}{l}\text { Sunrise (a } 5 \text { year programme of } \\
\text { work between Unilever and } \\
\text { Oxfam) - speakers from Oxfam } \\
\text { and Unilever and Universities }\end{array}$ & $\begin{array}{l}\text { Sourcing / } \\
\text { procurement strategies }\end{array}$ & $\begin{array}{l}\text { Unilever } \\
23 / 01 / 2015\end{array}$ & 153 & $\begin{array}{l}\text { https://www.youtube.com/watch?v=1Nb9zrf7Z } \\
\underline{\mathrm{aE}}\end{array}$ \\
\hline V9 & More Vanilla - Great Ice-cream & Images of vanilla producers. & Vanilla & $\begin{array}{l}\text { Unilever } \\
01 / 05 / 2015\end{array}$ & 3607 & $\underline{\mathrm{https}: / / \text { www.youtube.com/watch? } \mathrm{v}=\mathrm{ixnaqY} Y \mathrm{fi} 3}$ \\
\hline V10 & The value of empowering women & $\begin{array}{l}\text { Unilever / women in their various } \\
\text { roles }\end{array}$ & Role of women in $\mathrm{VC}$ & $\begin{array}{l}\text { Unilever } \\
24 / 04 / 2015\end{array}$ & 2923 & $\begin{array}{l}\text { https://www.youtube.com/watch? v=PWt1cit x } \\
\text { 7I\&index=1\&list=PLncvI6F uW pY0Gl34A }\end{array}$ \\
\hline
\end{tabular}




\begin{tabular}{|c|c|c|c|c|c|c|}
\hline & & & & & & V9jgNRcERZJ6KW \\
\hline V11 & Unilever: Empowering Women & Unilever / women / consumers & Role of women in $\mathrm{VC}$ & $\begin{array}{l}\text { Unilever } \\
02 / 07 / 2015\end{array}$ & 12426 & $\begin{array}{l}\text { https://www.youtube.com/watch?v=071k6- } \\
\text { 59rQ\&list=PLncvI6F_uW_pY0Gl34AV9jgN } \\
\text { RcERZJ6KW\&index }=8\end{array}$ \\
\hline V12 & Feeding the farmers that feed you & Unilever / consumers & $\begin{array}{l}\text { Tea, Cocoa, vanilla, } \\
\text { sugar, nuts }\end{array}$ & $\begin{array}{l}\text { Unilever } \\
30 / 08 / 2011\end{array}$ & 2348 & $\begin{array}{l}\text { https://www.youtube.com/watch?v=14V_dryo } \\
\text { K- } \\
\text { c\&index=1\&list=PLncvI6F_uW_oAosEwqCtt } \\
\text { PybKTAF126WF }\end{array}$ \\
\hline V13 & Sustainable Vegetables & Unilever, farmers, chefs & Vegetables (tomatoes) & $\begin{array}{l}\text { Unilever } \\
24 / 04 / 2012\end{array}$ & 4651 & $\begin{array}{l}\text { https://www.youtube.com/watch?v=anyw3Shc } \\
\text { ino\&index=2\&list=PLncvI6F uW_oAosEwq } \\
\text { CttPybKTAFl26WF }\end{array}$ \\
\hline V14 & Sustainable Sourcing & $\begin{array}{l}\text { Knorr, Knorr products, farmers, } \\
\text { machinery }\end{array}$ & Vegetables & $\begin{array}{l}\text { Unilever } \\
16 / 04 / 2013\end{array}$ & 18864 & $\begin{array}{l}\text { https://www.youtube.com/watch?v=- } \\
\text { eSJKNXsvwI\&index=4\&list=PLncvI6F uW } \\
\text { oAosEwqCttPybKTAFI26WF }\end{array}$ \\
\hline V15 & Vanilla sourcing in Madagascar & $\begin{array}{l}\text { Vanilla farmers, Unilever, } \\
\text { Symrise, GIZ }\end{array}$ & Vanilla & $\begin{array}{l}\text { Unilever } \\
28 / 01 / 2014\end{array}$ & 3225 & $\begin{array}{l}\text { https://www.youtube.com/watch?v=SHOE5dV } \\
\text { TQW4\&list=PLncvI6F_uW_oAosEwqCttPyb } \\
\text { KTAF126WF\&index=6 }\end{array}$ \\
\hline V16 & Barry Callebaut & Barry Callebaut employees & Cocoa & $\begin{array}{l}\text { Unilever } \\
02 / 02 / 2015\end{array}$ & 1343 & $\begin{array}{l}\text { https://www.youtube.com/watch? }=5 \text { ld6BLT } \\
\text { AfG4\&index=8\&list=PLncvI6F uW_oAosEw } \\
\text { qCttPybKTAFl26WF }\end{array}$ \\
\hline V17 & $\begin{array}{l}\text { The Morning Star Packing } \\
\text { Company: Unilever sustainable } \\
\text { sourcing with our suppliers }\end{array}$ & $\begin{array}{l}\text { The Morning Star Packing } \\
\text { Company }\end{array}$ & Tomatoes & $\begin{array}{l}\text { Unilever } \\
02 / 02 / 2015\end{array}$ & 1645 & $\begin{array}{l}\text { https://www.youtube.com/watch?v=pijkF6HY } \\
\text { Sws\&list=PLncvi6F uW_oAosEwqCttPybKT } \\
\text { AFl26WF\&index }=10\end{array}$ \\
\hline V18 & Unilever and sustainable palm oil & Unilever & Palm oil & $\begin{array}{l}\text { Unilever } \\
02 / 02 / 2015\end{array}$ & 468 & $\begin{array}{l}\text { https://www.youtube.com/watch?v=j1aZRDw } \\
\text { ZQbU\&list=PLncvI6F uW_oAosEwqCttPyb } \\
\text { KTAFI26WF\&index=11 }\end{array}$ \\
\hline V19 & $\begin{array}{l}\text { Local sustainable tomato sourcing } \\
\text { helps smallholder farmers and } \\
\text { grows the brand }\end{array}$ & $\begin{array}{lr}\text { Kisser, Unilever, } & \text { Indian } \\
\text { businesswoman, } & \text { Manisha } \\
\text { Shashikant (Varun } & \text { Argo } \\
\text { Processing Foods) } & \\
\end{array}$ & Tomatoes & $\begin{array}{l}\text { Unilever } \\
29 / 05 / 2015\end{array}$ & 2104 & $\begin{array}{l}\text { https://www.youtube.com/watch?v=115rEN- } \\
\text { bS58\&index=14\&list=PLncvl6F_uW_oAosE } \\
\text { wqCttPybKTAFl26WF }\end{array}$ \\
\hline V20 & $\begin{array}{l}\text { Winner announced of the first } \\
\text { HRH The Prince of Wales Young } \\
\text { Sustainability Entrepreneur Prize }\end{array}$ & $\begin{array}{l}\text { Projects in Mexico, Nigeria, } \\
\text { Guatemala, Nepal, Peru, India }\end{array}$ & $\begin{array}{l}\text { Focused on supporting } \\
\text { households } \\
\text { developing markets } \\
\text { (waste, water, feed, } \\
\text { electricity, crops, } \\
\text { education) }\end{array}$ & $\begin{array}{l}\text { Unilever } \\
02 / 02 / 2015\end{array}$ & 155 & $\begin{array}{l}\underline{\text { https: //www.youtube.com/watch?v=bQwgxT1 }} \\
\underline{\text { 5LFA }}\end{array}$ \\
\hline
\end{tabular}




\begin{tabular}{|l|l|l|l|l|l|l|}
\hline V21 & $\begin{array}{l}2015 / 2016 \text { Finalists: Unilever } \\
\text { Young Entrepreneur Awards }\end{array}$ & $\begin{array}{l}\text { Young entrepreneurs working in } \\
\text { Pakistan, Nepal, Ignitia, } \\
\text { Colombia, Cambodia, Guatemala } \\
\text { and Belize, Nigeria }\end{array}$ & $\begin{array}{l}\text { lealth care, weather } \\
\text { for yields, plastics, } \\
\text { cacao supply chain, } \\
\text { cassava }\end{array}$ & $\begin{array}{l}\text { Unilever } \\
17 / 05 / 2016\end{array}$ & 720 \\
\hline V22 & Certification vs Self Verification & $\begin{array}{l}\text { Unilever, Fair Trade, Rain Forest } \\
\text { Alliance }\end{array}$ & $\begin{array}{l}\text { General SC } \\
\text { ug }\end{array}$ & $\begin{array}{l}\text { Unilever } \\
02 / 02 / 2015\end{array}$ & 826 & $\begin{array}{l}\text { https://www.youtube.com/watch?v=xYsyReV } \\
\text { vZks }\end{array}$ \\
\hline
\end{tabular}




\section{Appendix 2 - Code map}

Sustainability Imaginary for Farmers in Global Supply Chains

Construction of sustainability and empowerment strategies

\begin{tabular}{|l|l|} 
Problematising approach to sustainability strategy: \\
Win-win framing of sustainability \\
Sustainability targets \\
Supply chain sustainability \\
Farming sustainability: \\
Yiclds \\
Quality \\
Access to market \\
Finance \\
Training Education
\end{tabular}

Empowerment to achieve U'nilever's goals

Empowerment through supply chain integration

Win-win framing of empowerment

Agents of empowerment

Empowerment as the means to achieve sustainability strategy

Mechanisms of empowerment:

Improved decision making concerning nutrition

Empowement through access to training

Empowerment through hygiene

Empowerment through gardening

Empowerment through promotion of rights

Empowerment of female farmets through voice giving

Empowerment of next gencration of farmers

\begin{tabular}{|l|}
\hline \multicolumn{1}{|c|}{ Construction of subject positions } \\
\hline 'Forse for good" \\
Omnipotence \\
Ownership of sustainability issues \\
Bencvolcnoe \\
Sustainability persons \\
Unilevericxtemal partiner merging \\
Business-centrism
\end{tabular}

\section{Representations of farmer:}

Happy and healthy farmers

Happiness and product quality

Beautiful landscapes for farming

Rosipisnts (of training, finanse...)

Colonial representation

Empowered females:

Family decision-makers

Gendered representations

Female farm wotkers

Western rs, non-Westin
"Voiseless" females

Decontertualisation: Unsustainable livelihoods, Increased dependence, Figure of the trader, Farmers' real desines, Stringent requirements, Absence of details on commercial relationships 